\title{
Título da página electrónica: Escola de Cultura de
}

Paz

Endereço: http://www.pangea.org/unescopau/castellano/

Mónica Rafael Simões

\section{OpenEdition}

\section{Journals}

Edição electrónica

URL: http://journals.openedition.org/rccs/1039

DOI: $10.4000 /$ rccs. 1039

ISSN: 2182-7435

\section{Editora}

Centro de Estudos Sociais da Universidade de Coimbra

Edição impressa

Data de publição: 1 junho 2005

Paginação: 177-178

ISSN: 0254-1106

Refêrencia eletrónica

Mónica Rafael Simões, «Título da página electrónica: Escola de Cultura de Paz », Revista Crítica de Ciências Sociais [Online], 71 | 2005, posto online no dia 01 outubro 2012, consultado o 22 setembro 2020. URL : http://journals.openedition.org/rccs/1039; DOI : https://doi.org/10.4000/rccs.1039 


\section{Espaço Virtual}

\section{Título da página electrónica: Transcend - A Peace and Development Organisation for Conflict Transformation by Peaceful Means Endereço: http://transcend.org}

Transcend é uma organização de mediação de conflitos que tem como objectivo colocar a experiência e o conhecimento ao serviço das práticas de transformação de conflitos, construção da paz e desenvolvimento. Fundada em 1993 por Johan Galtung - seu director e um dos pais fundadores dos estudos para a paz -, esta organização "virtual" baseia-se no trabalho e comunicação em rede e fundamenta-se em 4 pilares principais: educação/formação, disseminação, pesquisa e acção.

A acção para a tentativa de transformação pacífica de conflitos é desenvolvida através do método TRANSCEND, cujos princípios orientadores e código de conduta podem ser consultados on-line. Os resultados do trabalho são colocados na página da organização e actualizados ocasionalmente, fornecendo acesso a um importan- te conhecimento sobre cerca de 45 conflitos armados e seus processos de mediação. Convém, no entanto, referir que o enfoque do trabalho da organização e, consequentemente, da informação a que se tem acesso através da página se centra principalmente em propostas de solução e transformação. Nesta página é possível ainda ter acesso às bases teóricas e conceptuais da filosofia da paz que a organização visa implementar, bem como a informações sobre as publicações dos seus membros. A dimensão educação/formação merece uma referência particular. Esta é concretizada através da Transcend Peace University, uma rede de sites da organização, que fornece cursos on-line sobre temas como transformação de conflitos e construção da paz, reconciliação, democracia e direitos humanos ou jornalismo para a paz, entre outros.

\section{Título da página electrónica: Escola de Cultura de Paz Endereço: http://www.pangea.org/unescopau/castellano/}

A Escola de Cultura de Paz foi criada em 1999, dando seguimento à Cátedra UNESCO sobre Paz e Direitos Humanos da Universidade Autónoma de Barcelona, com o objectivo de trabalhar para uma cultura de paz, promovendo a investigação e formação em áreas relacionadas com prevenção e análise de conflitos, processos de paz, desarmamento, direitos humanos e educação para a paz.

Esta página é coordenada por Vicenç Fisas e produzida pela sua equipa de jovens investigadores da Universidade Autónoma de Barcelona. Na barra esquerda da página são apresentados os programas principais de investigação, onde importa destacar a "Unidade de Alerta". Este programa produz dois importantes boletins, Semáforo e Barómetro, com publicação semanal e trimestral, respectivamente. É importante destacar que Barómetro é um relatório de referência, publicado em castelhano e em inglês, com uma análise e acompanhamento de acontecimentos no âmbito mundial, através de nove secções: conflitos, tensões, processos de paz, reabilitação pós-bélica, 
crises humanitárias, militarização/desarmamento e direitos humanos. Um dos aspectos mais positivos a realçar nesta página é a qualidade da análise crítica presente nos relatórios, artigos e restantes publicações dos vários programas.

A página electrónica está disponível em duas línguas (castelhano e catalão) e per- mite a subscrição de boletins electrónicos relativos a todas as temáticas desenvolvidas. Merece ainda especial referência o link para o seu parceiro Canal Solidário/One World, portal de Internet de um projecto de comunicação sobre cooperação, desenvolvimento, paz, direitos humanos e inclusão social.

\section{Título da página electrónica: Fondation Hirondelle Endereço: http://www.hirondelle.org}

A Fundação Hirondelle, criada em 1995, é a única organização não governamental especializada de jornalistas que cria meios de comunicação social independentes e comprometidos com a causa democrática em zonas de crises ou de pós-conflito, com o objectivo de apoiar esforços de paz e de promover os direitos humanos.

Uma informação profissional, confiável e imparcial constitui um dos direitos humanos fundamentais e desempenha um papel central ou mesmo determinante em situações de conflito. Fornecer informações úteis a populações refugiadas ou deslocadas, informar com qualidade e independência pessoas a quem violenta e frequentemente se negou esse direito, pela submissão a propaganda, condicionamentos e sentimentos de ódio, e dar a palavra a todos os actores, incluindo a população tradicionalmente "sem voz", é, na perspectiva da Fundação, uma forma de devolver o respeito e a dignidade roubadas, de impedir futuras formas de manipulação e desinformação e de apoiar a construção de espaços tolerantes e participativos.

A página electrónica está disponível em quatro línguas (francês, inglês, alemão e italiano) e é de fácil navegação, constituin- do uma referência obrigatória para quem procure exemplos e reflexões práticas sobre a relação entre os meios de comunicação social e a construção da paz. Nela encontramos informações sobre os vários projectos radiofónicos desenvolvidos, entre os quais merecem destaque a Rádio Blue Sky, no pós-guerra do Kosovo, a Rádio Okapi, na República Democrática do Congo, ou os projectos de transmissões informativas para refugiados timorenses. Um elemento interessante que esta página oferece é o link para o projecto "Agência Hirondelle de Informação, Documentação e Formação", com oficina em Arusha, na sede do Tribunal Penal Internacional para o Ruanda, que produziu diariamente informação completa e profissional sobre as actividades do Tribunal, em quatro línguas (kinyarwanda, swahili, francês e inglês). Um dos aspectos mais inovadores e ricos desta página é a possibilidade de fazer download dos vários programas de rádio dos seus projectos, bem como os links para informação relevante sobre os conflitos de cada um dos países em que trabalha.

\section{Mónica Rafael Simões \\ mrafael@ces.uc.pt}

